\title{
Pengaruh Motivasi, Kepemimpinan, dan Budaya Organisasi terhadap Kinerja Karyawan di Lampung
}

\author{
Roy Saga \\ kiaysaga@gmail.com \\ UIN Raden Intan Lampung \\ Yani Setyawati \\ yani@gmail.com \\ UIN Raden Intan Lampung \\ Iwan Eko A \\ iwanekoariyadi@gmail.com \\ UIN Raden Intan Lampung \\ Vicky F Sanjaya \\ vicky@radenintan.ac.id \\ UIN Raden Intan Lampung
}

\begin{abstract}
Abstrak
Tujuan dari penelitian ini antara lain untuk mengetahui dan menganalisis pengaruh kepemimpinan, budaya organisasi dan motivasi terhadap kinerja pegawai di Daerah Lampung. Penelitian ini termasuk pada penelitian kuantitatif sebab pendekatan yang digunakan untuk usulan penelitian, proses, hipotesis, analisis data, kesimpulan data adalah pendekatan kuantitatif. Subyek penelitian adalah karyawan di daerah Lampung dengan jumlah 70 responden. Uji statistic dilakukan dengan menggunakan Structurel Equation Modelling berbasis PLS. Uji validitas menggunakan nilai faktor loading, sedangkan uji reliabilitas menggunakan nilai cronbach'c alpha, composite reliability dan Average Variance Extracted (AVE). Setelah seluruh hasil item indicator yang digunakan dalam penelitian ini valid dan reliabel, selanjutnyadilakukan uji hipotesis. Dari ketigahipotesis yang diajukan hanya dua yang terdukung, namun untuk hipotesis pertama tidak signifikan. Kesimpulan dari penelitian ini adalah bahwa sangat penting dalam perusahaan/organisasi memberikan motivasi kepada karyawan/anggota organisasi guna meningkatkan kinerjanya. Sama halnya dengan budaya oraganisasi, jadi semakin baik/semakin erat kekeluargaan di dalam suatu perusahaan/organisasi maka dapat meningkatkan kinerja karyawan/anggota yang nantinya akan berdampak baik bagi produktifitas perusahaan/organisasi.
\end{abstract}

Kata kunci: motivasi, kepemimpinan, budaya organisai, kinerja

\section{Pendahuluan}

Dalam persaingan global saat ini, organisasi perusahaan harus meningkatkan kinerja karyawan, maka diperlukan kemampuan sumber daya yang handal dan berkualitas. Salah satu langkah untuk mempertahankan atau meningkatkan kinerja karyawan dapat dilakukan dengan mengevaluasi kinerja karyawan dan melakukan serangkaian perbaikan agar selalu meningkatkan kualitas karyawan, sehingga perusahaan tumbuh dan unggul dalam persaingan.

Kinerja pada umumnya diartikan sebagai kesuksesan seseorang dalam melaksanakan suatu pekerjaan. (Mangkunegara, 2011) mengemukan bahwa kinerja adalah hasil kerja secara kualitas dan kualitas yang dicapai oleh seorang pegawai dalam melaksanakan tugasnya sesuai dengan tangung jawab yang diberikan kepadanya. Kinerja pegawai merupakan hasil kerja yang dicapai seseorang dalam melaksanakan tugas-tugas yang diberikan kepadanya untuk mencapai target kerja. Pegawai dapat bekerja dengan baik 
bila memiliki kinerja yang tinggi sehingga dapat menghasilkan kerja yang baik.

Kinerja pegawai merupakan salah satu faktor penentu keberhasilan instansi atau organisasi dalam mencapai tujuannya. Untuk itu kinerja dari pegawai dapat mempengaruhi kinerja instansi secara keseluruhan. Menurut (Kartono, 2016), kepemimpinan adalah kemampuan untuk memberikan pengaruh yang konstruktif kepada orang lain untuk melakukan satu usaha kooperatif mencapai tujuan yang sudah dicanangkan. Kualitas dari pemimpin dianggap sebagai faktor terpenting dalam keberhasilan atau kegagalan, demikian juga keberhasilan atau kegagalan suatu organisasi atau instantis biasanya dipersepsikan sebagai keberhasilan atau kegagalan pemimpin.

Pimpinan berkewajiban memberikan perhatian yang sungguh-sungguh untuk membina, mengerahkan, menggerakkan semua potensi pegawai di lingkungannya agar terwujud volume dan beban kerja yang terarah pada tujuan. Pimpinan perlu melakukan pembinaan yang sungguh-sungguh terhadap karyawan agar dapat menimbulkan kepuasan dan komitmen sehingga pada akhirnya dapat meningkatkan kinerja yang tinggi.

Selain kepemimpinan dan motivasi faktor lain yang mempengaruhi kinerja karyawan adalah budaya organisasi (Putranti, Megawati, \& Setyobudi, 2018). Pentingnya budaya organisasi, pemahaman budaya organisasi sebagai kesepakatan bersama mengenai nilai-nilai yang mengikat semua individu dalam sebuah organisasi untuk menentukan batas-batas normatif perilaku anggota organisasi. (Wijono, 2015) mengatakan bahwa budaya organisasi hanya memiliki efek positif berpengaruh dan tidak signifikan terhadap kepuasan kerja, tetapi kepuasan kerja memberikan dampak yang signifikan terhadap kinerja karyawan.

Secara spesifik, peranan budaya organisasi adalah membantu menciptakan rasa memiliki terhadap organisasi, menciptakan keterikatan emosional antara organisasi dan karyawan yang terlibat di dalamnya, membantu menciptakan stabilitas organisas sebagai sistem sosial dan menemukan pola pedoman prilaku sebagai hasil dari norma-norma kebiasaan yang terbentuk dalam keseharian. Dengan demikian budaya organisasi berpengaruh kuat terhadap perilaku para anggotanya. Kinerja yang tinggi dihubungkan dengan motivasi yang tinggi. Sebaliknya, motivasi yang rendah dihubungkan dengan kinerja yang rendah. (P. Siagian, 2010) mengemukakan bahwa motivasi merupakan daya dorong bagi seseorang untuk memberikan kontribusi yang sebesar mungkin demi keberhasilan organisasi mencapai tujuan. Kinerja seseorang kadang-kadang tidak berhubungan dengan kompetensi yang dimiliki, karena terdapat faktor diri dan lingkungan kerja yang mempengaruhi kinerja. Motivasi sebagai suatu tujuan atau pendorong, dengan tujuan sebenarnya tersebut yang menjadi daya penggerak utama bagi seseorang dalam berupaya dalam mendapatkan atau mencapai apa yang diinginkannya baik itu secara positif ataupun negatif.

\section{Tinjauan Pustaka}

\subsection{Pengaruh Motivasi terhadap Kinerja Karyawan}

Menurut (Rivai \& Mulyadi, 2012), ada beberapa asumsi dasar yang harus dipahami oleh seorang pemimpin berkenaan dengan motivasi atau pemberian motivasi pada karyawan yaitu motivasi umumnya dianggap sebagai suatu hal yang baik atau positif, motivasi merupakan salah satu faktor diantara sejumlah faktor yang dianggap dapat mempengaruhi kinerja karyawan, motivasi adalah suatu alat dimana pemimpin dapat mengatur hubungan kerja dalam organisasi. Menurut hasil penelitian (Harahap \& Tirtayasa, 2020) motivasi secara parsial berpengaruh positif dan signifikan yang artinya pengaruh kuat sekali terhadap kinerja karyawan. Sehingga motivasi sangatlah penting untuk menunjang kinerja karyawan, untuk itu dapat dipertahankan yang sudah baik namun perlu adanya dorongan motivasi bagi karyawan dengan memberikan pendidikan, pelatihan, atau workshop sehingga meningkatkan kinerja karyawan. Tetapi (Indahningrum, 2020) mengatakan Motivasi tidak berpengaruh terhadapa kinerja karyawan. Tetapi menurut (Andika, Agung, Intan, \& Putri, 2020) Motivasi kerja berpengaruh positif signifikan terhadap kinerja karyawan dengan nilai sig $<0,05$ ini berarti semakin tinggi motivasi kerja maka 
semakin tinggi kinerja karyawan. Hal ini di tegaskan oleh (Khairuzzaman, 2016) Motivasi memiliki pegaruh positif yang signifikan terhadap kinerja karyawan. Sehingga berdasarkan hal diatas, penulis membuat hipotesis:

\section{H1: Motivasi berpengaruh positif terhadap kinerja karyawan}

\subsection{Pengaruh Kepemimpinan terhadap Kinerja Karyawan}

Menurut (Gibson Ivancevich Donnely, 2010), keberhasilan perusahaan sangat ditentukan oleh efektivitas keberhasilan pemimpin dan pegawai dari semua divisi dalam perusahaan. Pendapat Gibson ini mempunyai konsekuensi adanya suatu tuntutan kepada perusahaan untuk lebih memperhatikan aspek-aspek kritis yang merupakan faktor penentu keberhasilan kinerja pegawai seorang pemimpin, sehingga pegawai dapat meraih Kinerja pegawai Pegawai. Sedangkan menurut (Nurhas, 2017) Peran kepemimpinan seorang pemimpin bisa mempengaruhi motivasi kerja, yang pada akhirnya mampu mempengaruhi kinerja pegawai pegawai. Sehingga, dapat ditarik kesimpulan jika kompensasi dan kepemimpinan tidak mampu mewujudkan motivasi kerja pegawai, maka tidak akan bisa mempengaruhi peningkatan kinerja pegawai. Tetapi menurut penelitian (Yurida, 2019) kepemimpinan tidak berpengaruh signifikan terhadap kinerja karyawan di Bank Muamalat KC Yogyakarta. Penelitian (Pt, Teduh, \& Kota, 2019) menegaskan bahwa kepemimpinan disimpulkan memberikan pengaruh signifikan terhadap kinerja karyawan, jika gaya kepemimpinan ditingkatkan melalui gaya berorientasi, gaya partisipatif dan gaya pengasuh, maka kinerja karyawan akan meningkat dan sebaliknya apabila gaya kepemimpinan karyawan menurun maka kinerja karyawan akan menurun juga. Sehingga penulis membuat hipotesis:

\section{H2: Kepemimpinan berpengaruh positif terhadap kinerja karyawan}

\subsection{Pengaruh Budaya Organisasi terhadap Kinerja Karyawan}

Perlunya budaya organisasi sebagai landasan norma-norma dan nilai-nilai untuk dianut dan diterapkan oleh karyawan dalam mewujudkan tujuan perusahaan. Karyawan yang bekerja berlandaskan budaya organisasi diharapakan mampu memberikan yang terbaik dan membawa pengaruh terhadap kepuasan kerja dari karyawan karena karyawan merasa nyaman di mana karyawan tersebut bekerja. Salah satu terpenuhinya kepuasan kerja karyawan tidak lepas dari adanya peranan dari budaya organisasi. Sedangkan menurut (Kepemimpinan et al., 2019) Berdasarkan hasil uji hipotesis menggunakan uji t diketahui bahwa secara parsial Budaya Organisasi tidak signifikan pengaruhnya terhadap kinerja karyawan di Bank Syariah Mandiri cabang Bitung. Hal ini berarti kinerja karyawan di Bank Syariah Mandiri cabang Bitung naik atau turun bukan karena dipengaruhi oleh budaya yang berlaku di perusahaan tersebut. Tetapi menurut (Panggabean, Soekapdjo, \& Tribudhi, 2020) Budaya organisasi mempunyai pengaruh yang positif dan signifikan terhadap kepuasan kerja, komitmen efektif, komitmen berlanjut, kinerja karyawan, tetapi tidak berpengaruh terhadap niat pindah kerja. Sehingga penulis membuat hipotesis:

\section{H3: Budaya organisasi berpengaruh positif terhadap kinerja karyawan}

\section{Metode Penelitian}

Penelitian ini merupakan penelitian survey dengan bantuan instrument kuesioner. Responden merupakan orang yang bekerja di suatu perusahaan/instansi dan anggota organisasi. Uji validitas instrumen penelitian menggunakan convergent validity dengan melihat nilai masing-masing indikator factor loading pada item kuesioner. Convergent validity akan di ukur dengan melihat nilai minimum factor loading masing-masing item indikator $\geq 0.6$ (Hair, Black, Babin, \& Anderson, 2010).

Pengujian reliabilitas dengan melihat internal konsisitensi dengan dengan melihat nilai cronbach's alpha minimal 0.6 (Cooper \& Schindler, 2014). Jumlah sampel yang diujikan dalam penelitian ini berjumlah 70 responden. Pengujian hipotesis dilakukan dengan bantuan aplikasi Smart PLS. 


\section{Analisis Data dan Pembahasan}

\subsection{Analisis Data}

Berdasarkan hasil uji yang dilakukan memiliki beberapa hasil diantaranya. Pertama terdapat beberapa item kuesioner yang gugur karena tidak memenuhi batas standar factor loading. Pada variabel budaya organisasi (BO) dari 5 tersisa 3 item. Motivasi (M) dan Kepemimpinan (K) tidak ada yang gugur.

Selanjutnya dilakukan pengujian ulang terhadap validitas konstruk sehingga didapat semua item indikator berada di atas standar nilai faktor loading di atas $>0.6$ sehingga berdasarkan (Hair et al., 2010) dianggap semua item tersebut valid. Pengujian terhadap reliabilitas memiliki nilai cronbach's alpha, composite reliability dan Average Variance Extracted (AVE) $>0.6$. Sehingga instrumen tersebut dianggap reliable dan memenuhi syarat untuk dilakukan pengujian hipotesis.

\subsubsection{Hasil Uji Reabilitas dan Validitas}

\section{a. Hasil Uji Validitas}

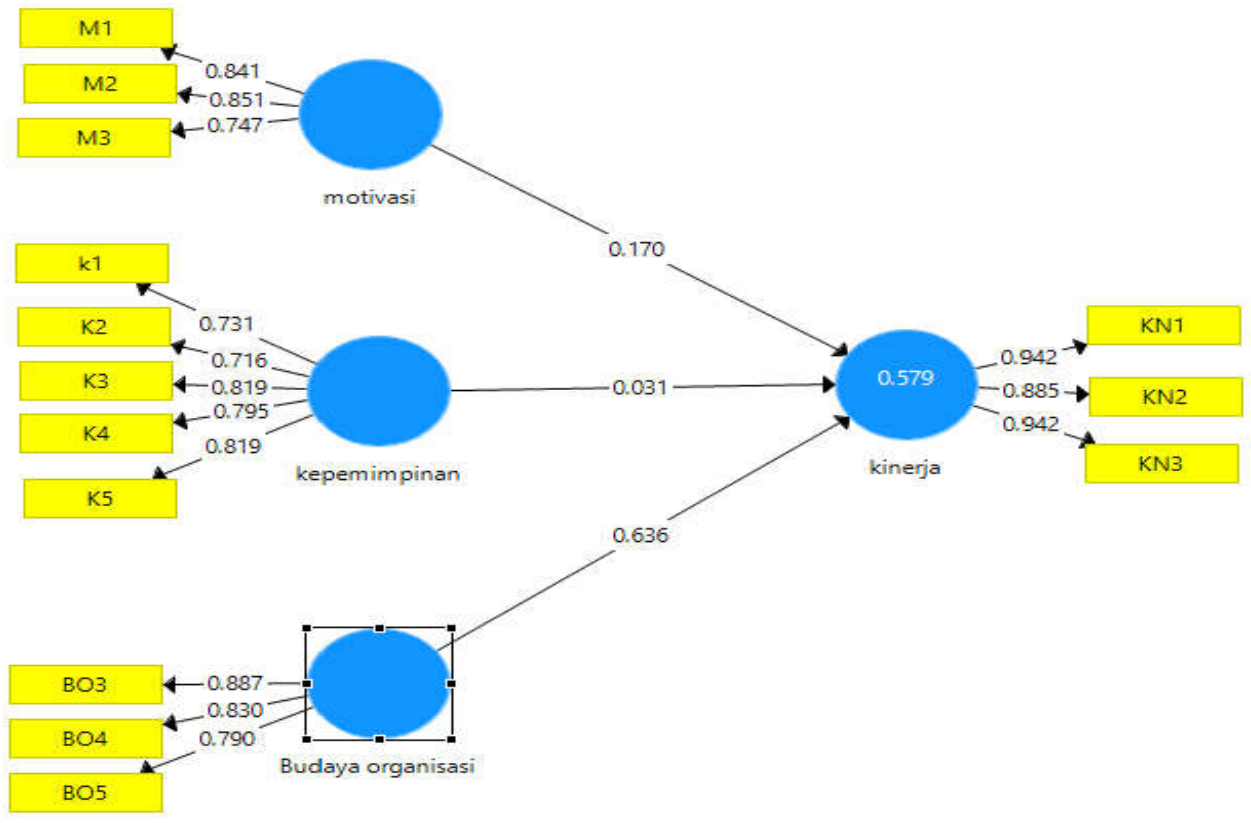

Gambar 1. Hasil Uji Validitas

Keterangan

$\begin{array}{ll}\text { M } & \text { : motivasi } \\ \text { K } & \text { : kepemimpinan } \\ \text { BO } & \text { : budaya organisasi } \\ \text { KN } & \text { : kinerja }\end{array}$

\section{b. Hasil Uji Reabilitas}

Tabel 1. Hasil Uji Reabilitas

\begin{tabular}{l|r|r|r|r|} 
& Cronbach's Al... & rho_A & Composite Rel... & Average Varian... \\
\hline Budaya organis... & 0.784 & 0.783 & 0.875 & 0.700 \\
\hline kepemimpinan & 0.837 & 0.844 & 0.884 & 0.604 \\
\hline kinerja & 0.913 & 0.919 & 0.945 & 0.853 \\
\hline motivasi & 0.761 & 0.818 & 0.855 & 0.663 \\
\hline
\end{tabular}




\subsection{Pembahasan}

Hipotesis 1: motivasi berpengaruh positif terhadap kinerja karyawan.

Berdasarkan hasil pengujian yang telah dilakukan didapatkan hasil bahwa motivasi berpengaruh positif terhadap kinerja karyawan namun tidak signifikan dengan nilai p-value $(0,203<0,05)$ sehingga hipotesis 1 terdukung.

Hipotesis 2: kepemimpinan berpengaruh positif terhadap kinerja karyawan

Berdasarkan hasil uji yang telah dilakukan, didapat nilai P-value $(0,863>0,05)$ sehingga hipotesis 2 tidak terdukung. Hal ini sejalan dengan penelitian (Yurida, 2019) kepemimpinan tidak berpengaruh signifikan terhadap kinerja karyawan.

Hipotesis 3: budaya organisasi berpengaruh positif terhadap kinerja karyawan

Berdasarkan hasil uji yang telah dilakukan, didapat nilai P-value $(0.001<0.05)$ sehingga dapat disimpulkan bahwa Hipotesis 3 terdukung. Budaya organisasi mempunyai pengaruh yang positif dan signifikan terhadap kinerja karyawan, dimana budaya organisasi yang baik membawa pengaruh yang baik terhadap kinerja karyawan. Sesuai dengan pendapat (Panggabean et al., 2020) budaya organisasi mempunyai pengaruh yang positif dan signifikan terhadap kepuasan kerja, komitmen efektif, komitmen berlanjut, kinerja karyawan, tetapi tidak berpengaruh terhadap niat pindah kerja.

Tabel 2. Uji Hipotesis

\begin{tabular}{|c|c|l|}
\hline No & Item & \multicolumn{1}{c|}{ Hasil } \\
\hline 1 & Hipotesis 1 & Terdukung \\
\hline 2 & Hipotesis 2 & $\begin{array}{l}\text { Tidak } \\
\text { terdukung }\end{array}$ \\
\hline 3 & Hipotesis 3 & Terdukung \\
\hline
\end{tabular}

\section{Kesimpulan dan Rekomendasi}

\subsection{Kesimpulan}

Berdasarkan hasil pengujian yang telah dilakukan di atas, dapat disimpulan bahwa pengaruh motivasi terhadap kinerja karyawan berpengaruh positif namun tidak signifikan. Bertolak belakang dengan pengaruh kepemimpinan terhadap kinerja karyawan yang berpengaruh negative. Sedangkan pengaruh budaya organisasi berpengaruh positif signifikan. Kita dapat menyimpulkan bahwa sangat penting dalam perusahaan atau organisasi melakukan motivasi kepada karyawan/anggota organisasi guna meningkatkan kinerjanya. Sama hal nya dengan budaya oraganisasi, jadi semakin baik/semakin erat kekeluargaan di dalam suatu perusahaan/organisasi maka dapat meningkatkan kinerja karyawan/anggota yang nantinya akan berdampak baik bagi produktifitas perusahaan/organisasi.

\subsection{Rekomendasi}

Berdasarkan kajian yang telah dilakukan dalam penelitian ini terdapat beberapa rekomendasi untuk penelitian mendatang, diantaranya penelitian selanjutnya dapat menambah lebih banyak jumlah reponden yang digunakan dan menambahkan variabel lain.

Rekomendasi bagi perusahaan/organisasi yang ada di lampung adalah, mengadakan seminar/rapat pemberian motivasi bagi karyawan/anggota guna meningkatkan kinerjanya dan membentuk budaya organisasi yang baik sesama anggota perusahaan. 


\section{Daftar Pustaka}

Andika, A. W., Agung, A., Intan, I., \& Putri, S. (2020). Karyawan Pada Hotel Griya Santrian. 15(2), 112-119.

Cooper, D. R., \& Schindler, P. S. (2014). Business Research Methods 12th Edition. In Business Research Methods.

Gibson Ivancevich Donnely. (2010). Organisasi dan Manajemen : Perilaku, Struktur dan Proses. In Organizational Behavior.

Hair, J. F., Black, W. C., Babin, B. J., \& Anderson, R. E. (2010). Multivariate Data Analysis. Vectors. https://doi.org/10.1016/j.ijpharm.2011.02.019

Harahap, S. F., \& Tirtayasa, S. (2020). Pengaruh Motivasi, Disiplin, Dan Kepuasan Kerja Terhadap Kinerja Karyawan Di PT. Angkasa Pura II (Persero) Kantor Cabang Kualanamu. Maneggio: Jurnal Ilmiah Magister Manajemen, 3(1), 120-135. https://doi.org/10.30596/maneggio.v3i1.4866

Kartono, K. (2016). Pemimpin dan Kepemimpinan, Apakah Kepemimpinan Abnormal Itu? In Rajawali Pers.

Kepemimpinan, P., Organisasi, B., Terhadap, D. A. N. K., Poluan, J. G., Ekonomi, F., \& Manajemen, J. (2019). Pengaruh Kepemimpinan, Budaya Organisasi, Dan Kompetensi Terhadap Kinerja Karyawan Pt. Bank Syariah Mandiri Cabang Bitung. Jurnal EMBA: Jurnal Riset Ekonomi, Manajemen, Bisnis Dan Akuntansi, 7(1), 31-40. https://doi.org/10.35794/emba.v7i1.22258

Mangkunegara. (2011). Manajemen Sumber Daya Perusahaan. In Manajemen Sumber Daya Perusahaan.

Nurhas, F. A. (2017). Jurnal Fakultas Ekonomi dan Bisinis Universitas TELKOM. Repository.Telkomuniversity.Ac.Id, 13(2), 896-908.

P. Siagian, S. (2010). Manajemen Sumber Daya Manusia. In Jakarta: cetakan kedelapan belas Bumi Aksara.

Panggabean, M. S., Soekapdjo, S., \& Tribudhi, D. A. (2020). Pengaruh Budaya Organisasi Terhadap Kinerja Karyawan di Era Millennial. Akuntabel, 17(1), 133-139.

Pt, P., Teduh, L., \& Kota, D. I. (2019). Jurnal Ilmiah FE-UMM. 13(1).

Putranti, H. R. D., Megawati, M., \& Setyobudi, S. (2018). Pengaruh Budaya Kerja Dan Komitmen Organisasi Terhadap Kinerja Melalui Motode TULTA Sebagai Variabel Kontrol. Jurnal Inspirasi Bisnis Dan Manajemen. https://doi.org/10.33603/jibm.v2i2.1556

Rivai, V., \& Mulyadi, D. (2012). Kepemimpinan dan Perilaku Organisasi. In Kepemimpinan dan Perilaku Organisasi.

Wijono, S. (2015). Psikologi Industri Dan Organisasi. Prenada.

Yurida, Y. (2019). Pengaruh Motivasi, Kompensasi, Dan Gaya Kepemimpinan Terhadap Kinerja Karyawan Di Bank Muamalat Kc Yogyakarta. Artikel Publikas: Universitas Islam Negeri Sunan Kalijaga. 